\title{
Field Straw Management - A Techno Economic Perspectives
}

\author{
S. Mangaraj and S.D.Kulkarni \\ Central Institute of Agricultural Engineering, Bhopal-462038 (M.P.) \\ Corresponding author e-mail: sukhdev1875@, rediffmail.com
}

\begin{abstract}
The study was conducted in the combine harvested paddy (variety-Kranti) and wheat (HI-8498) field. The crop gatherer cum baler was used for collection and baling of crop residues left in the field. Collection and gathering losses were determined for given condition and quantity of straw in the field. Moisture content of loose paddy and wheat straw was $15 \%$ and $8 \%$ respectively. Field operation was conducted at forward speed of $2.7 \mathrm{~km} / \mathrm{h}$ and with collecting width of $1240 \mathrm{~mm}$. The number of twine tied bales obtained per h was 181 and 87 with bale density of 200 and $102 \mathrm{~kg} / \mathrm{m}^{3}$ and bale mass of 22 and $10 \mathrm{~kg}$ respectively for rice and wheat crop. The collection and gathering losses were $18.40 \%$ for rice and $41.12 \%$ for wheat. The cost of producing one twine tied bale was Rs.2.75 and Rs.5.00 for rice and wheat respectively. At nominal price of rice straw (Rs. $0.25 / \mathrm{kg})$ and wheat straw (Rs. $0.75 / \mathrm{kg}$ ) the net income from straw collection and baling using the machine was Rs. 607.00 per ha and Rs. 235.00 per ha for rice straw and wheat straw respectively. Straw management in the combine harvested fields by straw collection and baling in the field is considered as an appropriate and economically viable option for timely use of the field for subsequent sowing.
\end{abstract}

\section{Introduction}

During the period of the green revolution major emphasis was given to enhance agricultural production. Forage crops, grasses and crop residues received relatively less priority. This has lead to a deficit of feed and fodder available to feed the millions of livestock in many parts of the country. In dairy production, the cost of feed constitutes about $60-65 \%$ of the total cost of milk production (Annon, 2009). Proper handling and conservation practices of forage crops and crop residues influence the effective utilization of fodder production. Transportation of high volume and low value crop residues is not economical. However, the need for transportation becomes very pressing during the period of need i.e. droughts and floods which occur very frequently in Nepal. Bulk density is more important for reducing the storage space requirement in handling and transportation (Yiljep, 1993).

The density of grasses and crop residue varies from $65-75 \mathrm{~kg} / \mathrm{m} 3$. Bale density achieved is in the range of $150-180 \mathrm{~kg} / \mathrm{m} 3$ and $350-450 \mathrm{~kg} / \mathrm{m} 3$. The reported cost of densification is Rs $80-100 / \mathrm{t}$, the transportation cost of loose fodder is Rs 408/t and high density fodder bale including cost of baling is Rs 196/t (Gupta et al. 1994). Use of large round bales reduces harvesting and handling cost as compared to small rectangular bales (Jankin et al 1985). In India, the concept of large round bales could not make any impact owing to scattered and small areas of grasslands. The efficiency of the straw harvesting could be increased by using high-density big rectangular bales: $1200 \times 850 \times 2200 \mathrm{~mm}, 160 \mathrm{~kg} / \mathrm{m} 3$ bale density (Hanel et al. 1990). 
Paddy and wheat crop was cultivated on 44.60 and 25.90 mha with a production of 93.10 MT and 71.80 MT respectively in the year 2009-10 (Agricultural Research Data Book, 2010). A Rice and wheat rotational system is being followed commonly. The combine harvested rice-wheat fields are generally left with long loose straw and stubbles in the field which create several operational problems in land preparation for the next crop. Nearly $75 \%$ of rice-wheat straw goes as waste besides causing environmental pollution due to straw burning in the field prior to tillage for subsequent sowings. Lack of suitable straw management practices for incorporation or retrieval of straws from combine harvested rice-wheat fields is the primary reason for straw burning. Retrieval of straw from combine harvested rice wheat fields was thus a challenge. Retrieved straw is useful as animal feed and for many industrial uses. The retrieval of straw can be done either by use of a straw baler or a straw harvester (Thakur et al. 2000). Keeping the need in view, an economic/suitability technological approach was assessed for straw collection and densification for easy handling and storage.

\section{Materials and Methods}

The commercial straw gatherer cum baler (CLASS MARCANT-55) (Fig.1 \&2) was used for field studies. The drive is taken from the tractor P.T.O. stub. The pick up width is $1240 \mathrm{~mm}$ and tractor power requirement of $30 \mathrm{KW}$ or larger for out put up to 16 tonnes per hour and bale size of $460 \times 360 \mathrm{~m}$ length infinitely variable from 400 to $1100 \mathrm{~mm}$ and bale weight from 10 to $35 \mathrm{~kg}$ depending on bale length and crop condition. The study was conducted in the 50 ha each of the combine harvested paddy, variety -Kranti and wheat, variety $-\mathrm{HI}-8498$ field at the Babai farm (Govt. of M.P.) (Fig. 2).

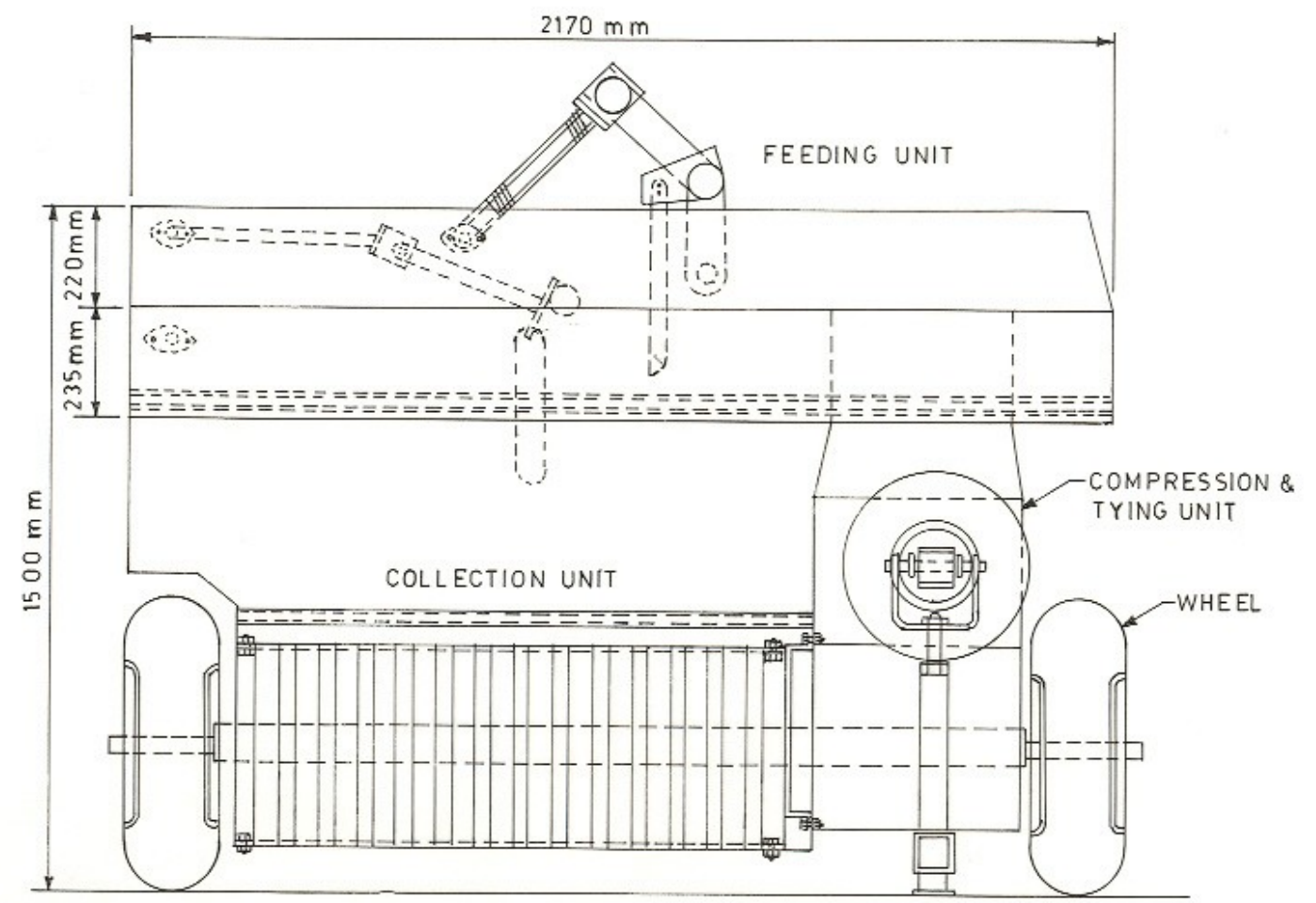

Figure 1: Line diagram of Baler 


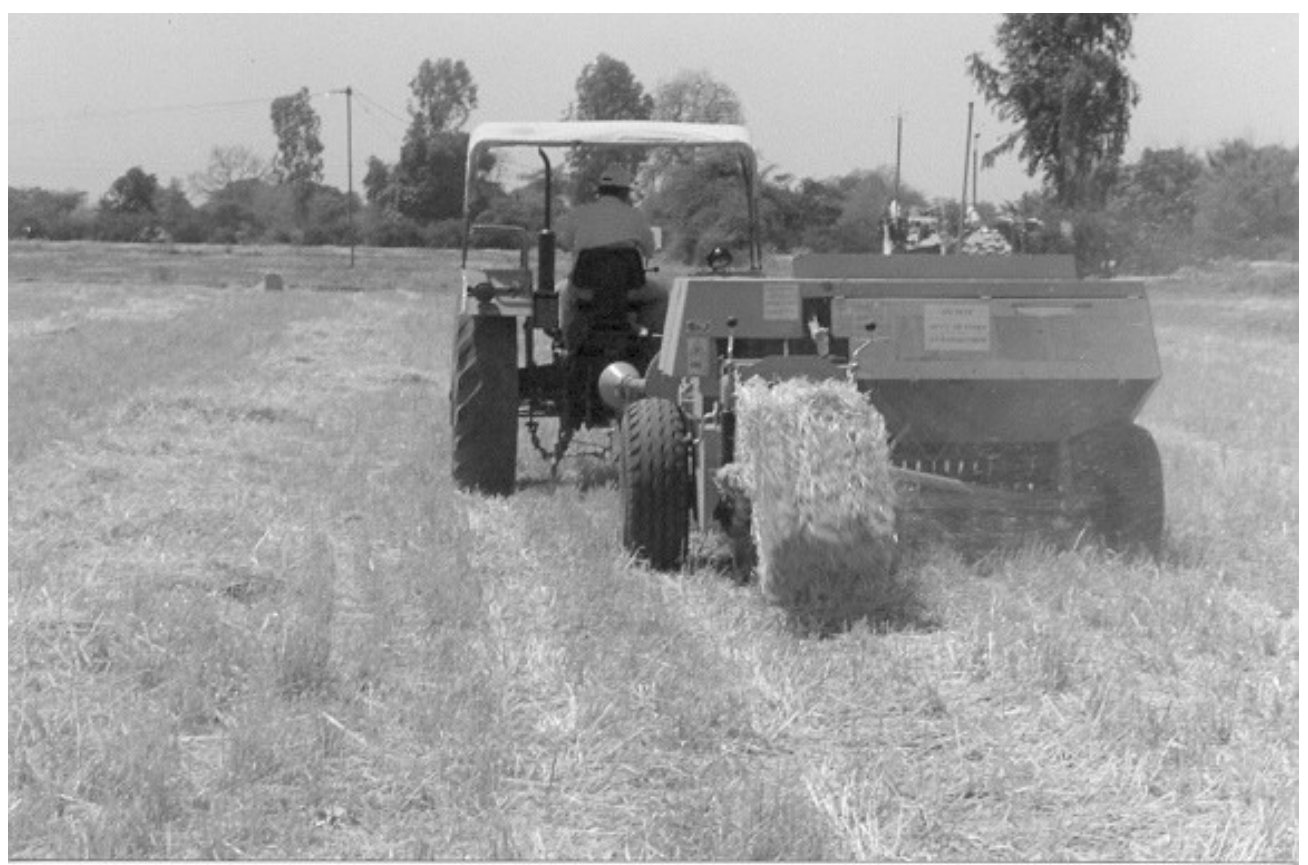

Figure 2: Operation of baler in the wheat field

The scope of the study was limited to measure the work rate, power requirement, size and quality of bales, mass of bale (Fig.3), twine consumption and comfort of operation. The amount of loose straw left in the field after combine harvesting was assessed by measuring size fractions, moisture content, swath width and distribution of loose straw per sq. m (straw density) besides measuring height and amount of cut stubbles with required field soil conditions. The loose straw from the field was picked up by the tines and fed to the bale chamber where it was trimmed, compressed and twine tied. The operation was continuous and bales were delivered into the field from the bale chamber (Fig.2).

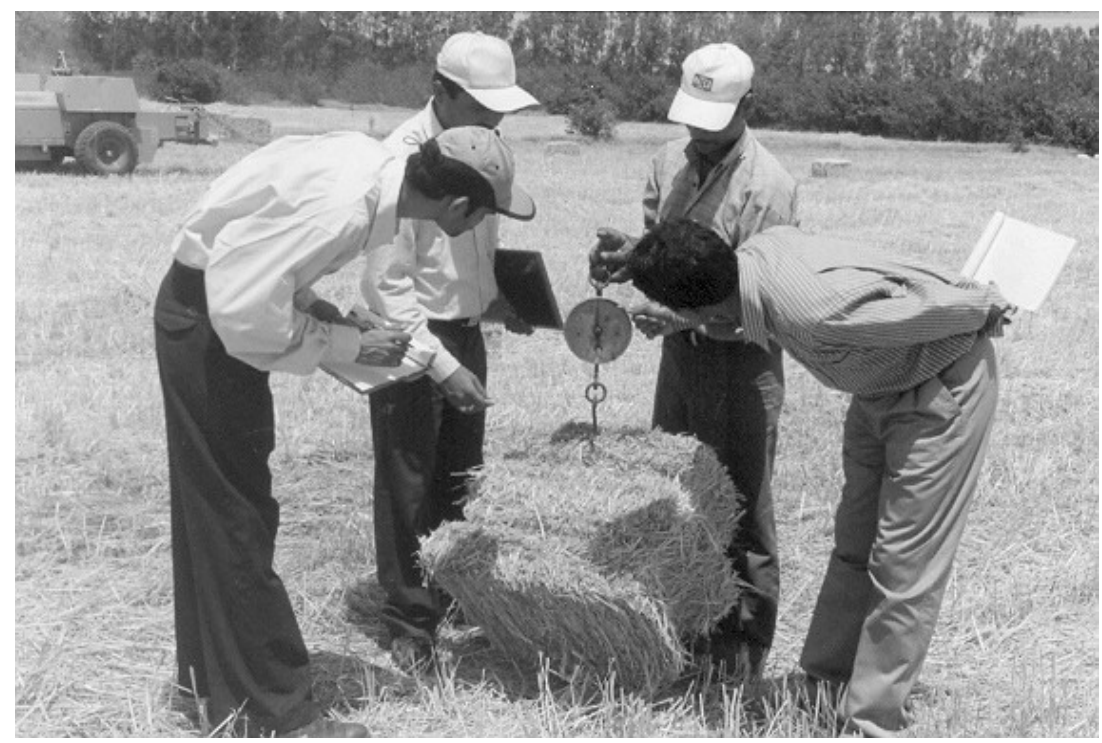

Figure 3: Measurement of weight of bale in the field 


\section{Results and Discussion}

The proportion by mass of straw in three size grade, namely $<50 \mathrm{~mm}, 50-150$ and $>150 \mathrm{~mm}$ long were determined. The median length of straw was found with the mean length of straw $>150 \mathrm{~mm}$ for both rice and wheat (Table-1). However, around $74 \%$ and $58 \%$ of straw length are $>150 \mathrm{~mm}$ for rice and wheat respectively.

Table-1: Length and mass of loose straw left in the field after grain combining.

\begin{tabular}{|l|c|c|c|c|}
\hline \multirow{3}{*}{ Crop } & \multicolumn{3}{|c|}{ Mass of straw, \% of total } & $\begin{array}{c}\text { Average length, } \\
\mathrm{mm}>150\end{array}$ \\
\cline { 2 - 5 } & Length, $\mathrm{mm}<50$ & Length, $\mathrm{mm} 50-150$ & Length, $\mathrm{mm}>150$ & \\
\hline Rice & 04 & 22 & 74 & 301.1 \\
\hline Wheat & 06 & 36 & 58 & 295.6 \\
\hline
\end{tabular}

The size of the field taken for study was $81 \times 52 \mathrm{~m}^{2}$ and $80 \times 50 \mathrm{~m}^{2}$ for rice and wheat respectively. The number of hills $/ \mathrm{m}^{2}$ was 23.50 for rice and 21.00 for wheat. The background data on the field straw condition (Table-2) a reveals that these conditions were like similar for rice and wheat crop. The moisture content of straw was $15 \%$ and $8 \%$ for rice and wheat respectively.

Table-2: Field straw condition

\begin{tabular}{|c|l|c|c|}
\hline S. No & Parameter & Rice & Wheat \\
\hline 1 & Height of stubble after combine harvesting, mm & 300 & 320 \\
\hline 2 & Amount of loose straw, g/m2 & 450 & 431 \\
\hline 3 & Moisture Content of straw, wb & 15 & 8 \\
\hline 4 & Length of loose straw, mm & 207 & 211 \\
\hline
\end{tabular}

At tractor linear speed of $2.78 \mathrm{~km} / \mathrm{h}$, the forward speed of baler was around $2.70 \mathrm{~km} / \mathrm{h}$ with collecting width of baler as $1240 \mathrm{~mm}$ for both rice and wheat crop. The field performance of the baler is given in Table-3. The baler was evaluated for bale size of $60 \times 38$ x $48 \mathrm{~cm}$. During the operation of baler in the field the material (straw) being picked up is received by the feed chamber which in turn pushes it to the bale chamber with the help of feeder forks. In the bale chamber the materials compressed with the help of plunger operating at 80 strokes per minute corresponding to $540 \mathrm{rpm}$ of the fly wheel. While the bale is being formed the twine disc holds the top strand of the twine. The needle coming up through the crop places the bottom stand of the twine in the twine disc. As the twine finger moves to the rear it pulls the twine together. When the twine disc commences to revolve it holds both strands of twine. The bottom stand is held tightly by the twine finger against the bill hook as the later starts to rotate. The twine disc rotates to the next notch position while the bill hook revolves to form a loop and opens to take grip of twine. The needle moving downward inserts the twine in the next notch position in the twine disc. The bill hook finishes revolving and closes on the twine. The twine is cut by the twine knife and the striper sweeps it from the bill hook and the knot is completed.

The baler was tested in 50 ha each of paddy and wheat field at forward speed of $2.7 \mathrm{~km} / \mathrm{h}$ having collecting width of $1240 \mathrm{~mm}$. The number of twine tied bales of paddy straw obtained per h was 181 with bale density of $200 \mathrm{~kg} / \mathrm{m}^{3}$ and bale weight of $22 \mathrm{~kg}$ (Table-3) and respective data for wheat straw is 87,102 and 10 respectively. The variation is basically due to variation in straw bulk density and straw spread density. Also the mass of bale is affected by the moisture content 
of the straw. The cost of producing one twine tied bale was Rs.2.75. for rice and Rs. 5.00 wheat respectively.

Table-3: Field performance of straw baler in the combine harvested rice and wheat fields.

\begin{tabular}{|l|c|c|}
\hline \multicolumn{1}{|c|}{ Particulars } & Rice & Wheat \\
\hline Size of bale, $\mathrm{cm}$ & $60 \times 38 \times 48$ & $60 \times 38 \times 48$ \\
\hline Effective field capacity, ha/h & 0.82 & 0.93 \\
\hline Field efficiency, $\%$ & 87.2 & 70.50 \\
\hline No. of bales/h & 184 & 89 \\
\hline Twine tied bales, Nos/h & 181 & 87 \\
\hline Untied bales, Nos/h & 3 & 2 \\
\hline Untied bales, $\%$ & 1.6 & 2.24 \\
\hline Twine used (nylon, dia. $2.03 \mathrm{~mm}, \mathrm{~g} / \mathrm{m}=2.97)$ used per bale, $\mathrm{m}$ & 3.57 & 3.50 \\
\hline Average fuel consumption, $1 / \mathrm{h}$ & 3.14 & 3.23 \\
\hline Density of bale, $\mathrm{kg} / \mathrm{m} 3$ & 200.38 & 102 \\
\hline Mass of bale, kg & 22 & 10 \\
\hline Labour requirement & 2 & 2 \\
\hline Average cost of operation of baler with tractor, Rs./h & 385 & 385 \\
\hline Cost of twine tied bale, Rs & 2.75 & 5.00 \\
\hline Net income, Rs/bale, Rs/ha & $3.38,1236$ & $3.25,633$ \\
\hline
\end{tabular}

\section{Collection and Gathering Losses}

The collection and gathering losses were estimated to be $18.40 \%$ and $41.12 \%$ for rice and wheat crop (Table-4). The higher value of loss for wheat straw is mainly due to relatively soft surface which leads to slippage during collection and gathering process.

Table -4: Collection and gathering losses in combine-harvested paddy and wheat field.

\begin{tabular}{|c|c|c|c|c|}
\hline S. No. & Field & $\begin{array}{c}\text { Straw left on the field after } \\
\text { combine harvester } \\
\text { operation, } \mathrm{kg} / \mathrm{m}^{2}\end{array}$ & $\begin{array}{c}\text { Straw left on the field after } \\
\text { straw baler operation, } \\
\mathrm{kg} / \mathrm{m}^{2}\end{array}$ & $\begin{array}{c}\text { Collection and } \\
\text { Gathering losses, \% }\end{array}$ \\
\hline 1. & Rice & 2.45 & 0.45 & 18.40 \\
\hline 2. & Wheat & 3.54 & 1.45 & 41.12 \\
\hline
\end{tabular}

\section{Economic perspective of baling of rice and wheat straw}

The cost economics was worked out (Table-5) based on work rate and actual output of bales per ha. The cost of twine used per bale was added to the unit cost of baling.

Thus the net income from the intervention of field collection, gathering and baling of straw could be Rs. 607.00 and 235.00 per ha for rice straw and wheat straw respectively besides avoiding environmental pollution on account of field burning of straw. The details of the economic tolls of baling were calculated. The break even point, return on investment and payback period was 
estimated to be 91743 bales, $21 \%$ and 5 years respectively. However the recovery of straw is dependent on the amount of loose straw left on the field after grain combining and the height of cut. Also, the profitability of in field baling may be more pronounced depending on the end use of straw retrieved and related variations in the price structure.

Table-5: Economics of baling of rice and wheat straw

\begin{tabular}{|l|c|c|}
\hline \multirow{2}{*}{\multicolumn{1}{|c|}{ Particulars }} & \multicolumn{2}{c|}{ Value(s) } \\
\cline { 2 - 3 } & Rice straw & Wheat straw \\
\hline Cost of operation of baler with tractor, Rs/h (Rs/ha) & $385(470)$ & $385(414)$ \\
\hline Bale out put, Nos/ha & 221 & 94 \\
\hline Cost of baling, Rs/bale & 2.12 & 4.40 \\
\hline Cost of twine used, Rs/bale & 0.63 & 0.63 \\
\hline Cost of twine tied bale, Rs/bale & 2.75 & 5.00 \\
\hline Cost of baling, Rs/ha & 608.00 & 470 \\
\hline Mass of straw bale, kg & 22 & 10 \\
\hline Cost* of bales/straw collected per ha & 1215.00 & 705.00 \\
\hline Net income (Rs/ha), Rs/unit bale & $607.00,2.75$ & $235.00,2.50$ \\
\hline
\end{tabular}

${ }^{*}$ Sale price of rice straw, $\mathrm{Rs} / \mathrm{kg}=0.25$ and wheat straw, $\mathrm{Rs} / \mathrm{kg}=0.75$

\section{Conclusions}

a. The cost of collection, gathering and baling was found to be Rs. 2.75 per bale at density of $200 \mathrm{~kg} / \mathrm{m}^{3}$ and Rs. 5.00 at density of $102 \mathrm{~kg} / \mathrm{m}^{3}$ for rice and wheat respectively. The only twine cost for tying of $60 \times 30 \times 48 \mathrm{~cm}$ bale is Rs. 0.63 .

b. At the nominal selling price of rice straw (Rs. 0.25/kg) and wheat straw (Rs. $0.75 / \mathrm{kg}$ ) the net income from baling was Rs. 607.00 per ha and Rs. 235.00 per ha for rice straw and wheat straw respectively.

c. The field straw collection, gathering and baling was considered to be a more appropriate approach of straw management to make the field free of loose straw without straw burning in the field.

\section{REFERENCE}

1. Agricultural Research Data Book (2010). Indian Agricultural Statistical Research Institute, ICAR, New Delhi.

2. Anon (2009). A report on Baling, Densification and Storage of grasses, fodder and crop residues" for NATP-PSR-39 at CIAE, Bhopal presented in 2nd workshop held at IGFRI, Jhansi during December 19-20 2002.

3. Gupta, P. D., Goyal, R. K. and Chattopadhyay, P. S. (1994). High density baling machine for economic transport and storage of grasses and crop residues- a step towards fodders bank: Indian farming. pp. 10-13. 
4. Jankins, B. M., Toenjes, D. A., Dobie, J. B. and Arther, J. F. (1985). Performance of large balers for collecting rice straw. Trans. ASAE, 28: 360-363.

5. Hanel-V and Marx-W (1990). Mechanization of grain production processing-Proceeding of the 4th international scientific conference held at Halle/Saale German-Democratic-Republic-17-19 October1989 [-S-Dammer (ed.). pp.218-222.

6. Thakur, T. C., Bamaga, O. A. and Verma, M. L. (2000). Collection, densification and utilization of paddy and wheat straw - present status and future Prospective, Agricultural Engineering Today. 24(4): 1-16.

7. Yiljep, Y. D., Bilanski, W. K. and Mittal, G. S. (1993). Porosity in Large Round Bales of Alfalfa Herbage. American Society of Agricultural Engineers. 36(2): March-April.1993. 